\title{
Method for Rapid Counting of Sporangia in the Green Alga Batophora Oerstedii
}

\author{
S. Bonotto and A. Lüttke \\ Department of Radiobiology, C.E.N./S.C.K., 2400 Mol, Belgium
}

Several species of green marine algae (Dasycladaceae) have been object of ecological investigations in recent years (Arasaki and Shihira-Ishikawa 1979; Cinelli, 1979; Liddle, 1979). Nevertheless, most data accumulated do not permit good estimation of their reproductive potential. This may be appraised by counting the total number of sporangia (S) and gametangia (cysts, C), assuming that the number of gametes $(G)$ in the cysts does not undergo large variations. If all male and female gametes form pairs, the theoretical total number of zygotes ( $Z$ ) per plant would be: $Z=1 / 2$ SCG. Thus far the total number of sporangia and/or gametangia has not been counted because of technical difficulties.

We found that photographic recording of fertile whorls of mature cells of Batophora oerstedii J. Agardh with a Polaroid camera mounted on a stereomicroscope permits rapid counting of the total number of sporangia. Mature B. oerstedii cells bear numerous fertile whorls serially distributed on the stalk (Fig. 1a). In cells of similar length the number of whorls may vary from one individual to another (Hämmerling, 1944). Moreover, under usual culture conditions, short cells $(1-1.5 \mathrm{~cm})$ have only $1-2$ fertile whorls on the apical region of the stalk, with large sporangia (Fig. 1b).

Figure 2 shows photographic recordings of the 14 fertile whorls of a normal Batophora oerstedii cell with a total of 214 sporangia. It clearly demonstrates that the number of sporangia per whorl varies considerably along the stalk. On the contrary, the number of hairs per whorl remains rather constant $(7-8)$, with the exception of the apical whorl, which has 6 hairs only. The photographic recordings show that sporangia
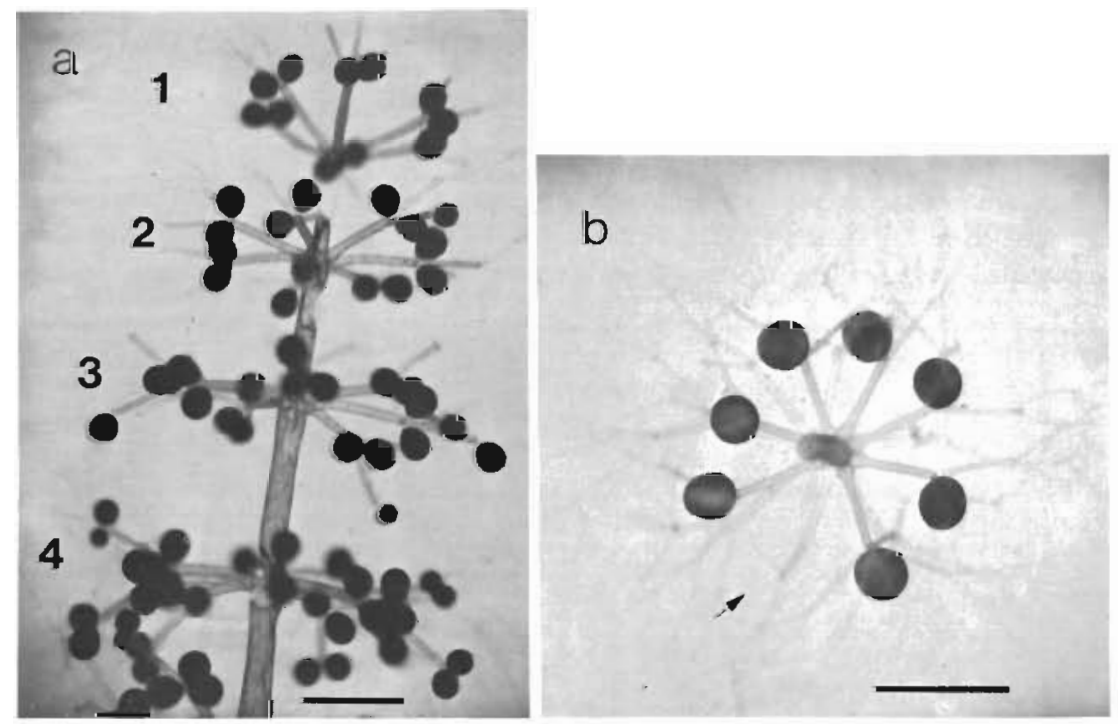

Fig. 1. (a) Batophora oerstedii. Apical stalk region of mature cell. Whorls, numbered 1 to 4 from apex, are serially distributed on the stalk. Scale $=1 \mathrm{~mm}$. (b) Fertile whorl with 7 large sporangia, developed by a short $(1.5 \mathrm{~cm})$ cell. One of the whorl hairs is sterile (arrow). Scale $=2 \mathrm{~mm}$ 
developed by second-order articles are smaller than those of the first-order article (Figs 2,2 and 3). Careful counting revealed that the sporangia of first-order articles contain twice as many cysts as those of secondorder articles (Table 1). Table 1 further demonstrates that the few large sporangia of short cells (Fig. 1b) have a large number of cysts. The $B$. oerstedii cell shown in Figure 2 possesses 158 first- and 56 secondorder sporangia, totaling 17,430 cysts. Unfortunately, the average number of gametes per cyst is still unknown. Schulze (1939) found that 2 cysts of another Dasycladacean alga, Acetabularia mediterranea, had 1175 and 2359 gametes, respectively. If $B$. oerstedii cysts contain a number of gametes lying in the same range, the cell shown in Figure 2 would produce about $10^{7}$ zygotes. The method reported here may also be useful for counting the total number of cysts in other species of the Dasycladaceae.
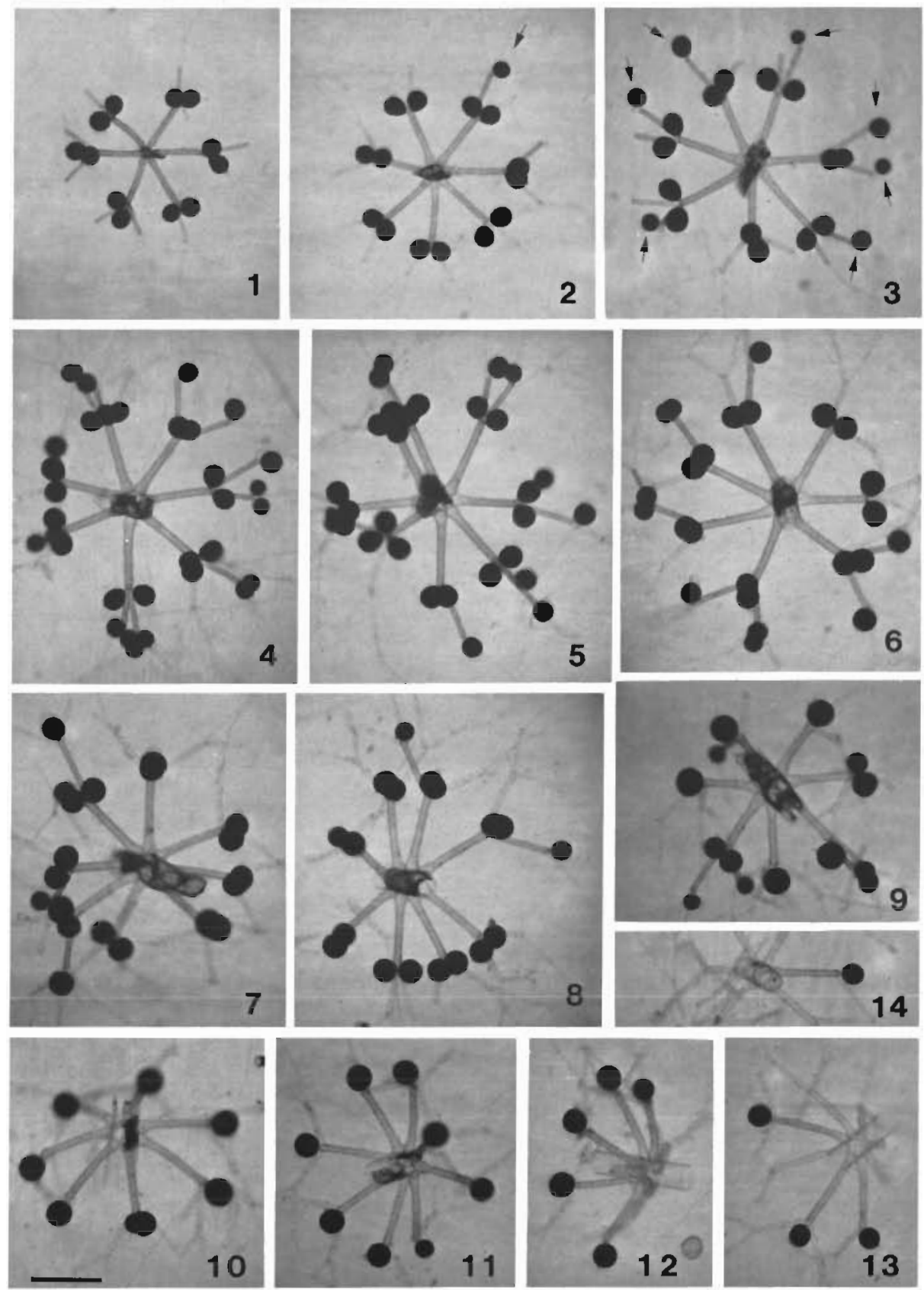

Fig. 2. Batophora oerstedii. Photographic recordings of 14 fertile whorls, formed by a normal cell, showing distribution of sporangia and hairs per whorl. Sporangia of second-order articles (arrows in 2 and 3) are generally smaller than those of firstorder articles. Scale $=1 \mathrm{~mm}$ 
Table 1. Batophora oerstedii. Number of cysts in sporangia developed by first-and second-order articles of normal plants and in large ones formed by short cells $(1-1.5 \mathrm{~cm})$ with only 1-2 fertile whorls. The sporangia were cut from different plants with fine scissors

\begin{tabular}{|cccc|}
\hline $\begin{array}{c}\text { Sporan- } \\
\text { gium }\end{array}$ & $\begin{array}{c}\text { Number of cysts } \\
\text { on second-order } \\
\text { articles }\end{array}$ & $\begin{array}{c}\text { on short cells } \\
\text { articles }\end{array}$ \\
\hline 1 & 135 & 93 & 352 \\
2 & 98 & 32 & 350 \\
3 & 92 & 49 & 387 \\
4 & 106 & 62 & 242 \\
5 & 73 & 35 & 356 \\
6 & 80 & 40 & 346 \\
7 & 63 & 44 & 346 \\
8 & 82 & 43 & 350 \\
9 & 54 & 40 & 281 \\
10 & 60 & 50 & 333 \\
11 & 95 & 34 & 339 \\
12 & 175 & 73 & 383 \\
Mean & $92.75 \pm 32.77$ & $49.58 \pm 17.35$ & $338.75 \pm 38.56$ \\
\hline
\end{tabular}

Acknowledgements. We are grateful to Professor Simone Puiseux-Dao, University of Paris VII, for the supply of Batophora oerstedii cells and to Mr. Albert Bossus for assistance.

\section{LITERATURE CITED}

Arasaki, S., Shihira-Ishikawa, I. (1979). Distribution and ecology of Acetabularia in Japan. In: Bonotto, S., Kefeli, V. Puiseux-Dao, S. (eds) Developmental biology of Acetabularia. Elsevier/North-Holland Biomedical Press, Amsterdam-New York-Oxford, pp. 15-18

Cinelli, F. (1979). Acetabularia acetabulum (L.) Silva Acetabularia parvula Solms-Laubach and Dasycladus vermicularis (Scopoli) Krasser (Chlorophyta, Dasycladaceae): Ecology and distribution in the Mediterranean Sea. In: Bonotto, S., Kefeli, V., Puiseux-Dao, S. (eds) Developmental biology of Acetabularia. Elsevier/NorthHolland Biomedical Press, Amsterdam-New York-Oxford, pp. 3-14

Liddle, L. B. (1979). Modes of reproduction in Cymopolia barbata (Chlorophyta, Dasycladales). In: Bonotto, S., Kefeli, V., Puiseux-Dao, S. (eds) Developmental biology of Acetabularia. Elsevier/North-Holland Biomedical Press, Amsterdam-New York-Oxford, pp. 19-26

Hämmerling, J. (1944). Zur Lebensweise, Fortpflanzung und Entwicklung verschiedener Dasycladaceen. Arch. Protistenk. 97: 7-56

Schulze, K. L. (1939). Cytologische Untersuchungen an Acetabularia mediterranea und Acetabularia wettsteinii. Arch. Protistenk. 92: 179-225 